光学的性質及び比重の測定値を次に示す。

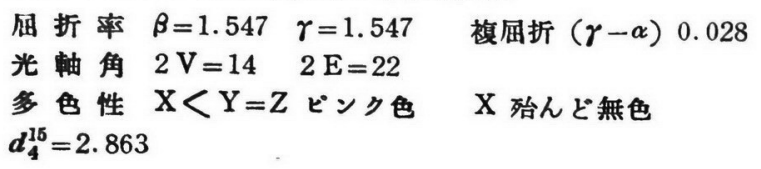

前の雲母 $母^{1)}$ と同様にして吸光係数を測定した。試料板の試料寸 泆は $103.3 \mathrm{mg} / 3.36 \mathrm{~cm}^{2}$, 厚さ $10.7 \times 10^{-3} \mathrm{~cm}$ であつた。透過率 の測定值より $1 \mathrm{~mm}$ の厚さに換算した吸光係数を求め第 2 四に示 した。ピンク色の㙁化コバルトの水溶液及びピンク色のガラスは 何孔る $520 \mu \mu$ の所に吸収がある。合成雲母の場合にはその附近 か平かとなつたのは $\mathrm{CoO}$ による吸収と雲母中の $\mathrm{Fe}_{2} \mathrm{O}_{3}$ による吸 収とが重り合つたためと思われる。このことより雲母中のコバル トは正八面体配位をとり Co++であると推察される。

合成雲母の化学分析は前雲母1)と同様にして行つた。倘鉄は $\mathrm{Fe}_{2} \mathrm{O}_{3}$ として定量し，次の結果を得た。 $\mathrm{K}_{2} \mathrm{O} 10.84 \% ， \mathrm{CoO} 1.84$ $\%, \mathrm{SiO}_{2} 42.19 \%, \mathrm{Al}_{2} \mathrm{O}_{3} 13.53 \%, \mathrm{MgO} 29.15 \%, \mathrm{~F} 8.13 \%$, $\mathrm{Fe}_{2} \mathrm{O}_{3} 0.76 \%$ 。

これより次の化学式を得た。

$\left(\mathrm{F}_{1.78} \mathrm{O}_{0.33}\right) \mathrm{K}_{0.93} \mathrm{Mgg}_{3.99} \mathrm{Fe}_{0.04} \mathrm{CO}_{0.10}\left(\mathrm{Al}_{1.10} \mathrm{Si}_{2.91} \mathrm{O}_{10.00}\right)$
この式より雲母中のコバルトは正八面体配位をとつていると判 断される。このことは前述の吸光係数の測定結果と一致してい る。

$$
\text { 結 言 }
$$

金雲母中の正四面体配位をとるアルミニウムの一部をコバルト で置きかえることにより青色雲母を又八面体配位をとるマグネシ ウムの一部をコバルトで置きかえることによりピンク色の雲母を 得た。化学分析及び吸光係数測定結果より次の化学式を与去た。

1. 青雲母 $\left(\mathrm{F}_{1.81} \mathrm{O}_{0.19}\right) \mathrm{K}_{0.94} \mathrm{Mg}_{2.83} \mathrm{Al}_{0.21}\left(\mathrm{Al}_{0.18} \mathrm{~B}_{0.23} \mathrm{Co}_{0.33}\right.$ $\mathrm{Si}_{3.27} \mathrm{O}_{10.00}$ 。

2. ピンク雲母 $\left(\mathrm{F}_{1.78} \mathrm{O}_{0.22}\right) \mathrm{K}_{0.95} \mathrm{Mg}_{2.99} \mathrm{Fe}_{0.04} \mathrm{Co}_{0.10}\left(\mathrm{Al}_{1.10}\right.$ $\mathrm{Si}_{2.91} \mathrm{O}_{10.00}$ )。

佾これ等の雲母につき比重, 光学的性質を測定し生成状態を顕 徽鏡的に観察した。

(昭和 25 年 11 月 11 日 日本化学会東海支部講演) 本研劣に関し終始御指導を睗つた野田教授及び化学分析につい て御援助を得た平尾䅹氏に深謝の意を表する。侣研究費の一部は 文部省科学研究費によつたてとを附記して感謝の意を表する。

（名古屋大学工学部応用化学教室）（昭和 26 年 11 月 22 日受理）

（158）鉄 雲 母 の 合 成

大門 信 利

金重母の理想式 $\mathrm{F}_{2} \mathrm{KMg}_{3}\left(\mathrm{AlSi}_{3} \mathrm{O}_{10}\right)$ 中の正四面体配位をとつ ているァルミニウムを, $\mathrm{Fe}^{3+} て ゙$ 置きかえた $\mathrm{F}_{2} \mathrm{KMg}_{3}\left(\mathrm{FeSi}_{3} \mathrm{O}_{10}\right)$ を合成し，また正八面体配位をとつているマグネジムの一部を $\mathrm{Fe}^{3+}$ Zる゙ $\mathrm{Fe}^{2+}$ て置きかえようとした。

原料にはマンガン雲母1) の合成の際に用いたと同じ珪弗化カ リ，、クネシア，アルミナ, 無水珄酸及び化学用酸化第一鉄, 酸 化第二鉄を夫々化学分析して用いた（用いたクリプトル電気炉の 家囲気は幾分酸化性であつた)。

\title{
(1) FeIII-雲母の合成
}

$\mathrm{F}_{2} \mathrm{KMg}_{3}\left(\mathrm{FeSi}_{3} \mathrm{O}_{10}\right)$ に相当する雲母を合成しよ 5 とした。本 合成实験に対する予備実験は既に前報”)で発表した。

第 1 表 $\mathrm{A}$ の組成の原料 $400 \mathrm{~g}$ を内容 $400 \mathrm{cc}$ の磁製坩堝中にと ク,クリプトル電気炉にて $1300^{\circ} \mathrm{C}$ にて熔融し, 電流を切つて放 冷した。得た褐色の雲母の中で最大の単結晶は $5 \mathrm{~mm}^{2}$ であつた。

目的とす百零母
A. $\mathrm{F}_{2} \mathrm{KMg}_{3}\left(\mathrm{FeSi}_{3} \mathrm{O}_{40}\right) \quad\left\{\begin{array}{c}\mathrm{M} \text { 比 } \\ \%\end{array}\right.$
B. $\mathrm{F}_{2} \mathrm{KMg}_{2} \mathrm{Fe}_{0.3}\left(\mathrm{AlSi}_{3} \mathrm{O}_{10}\right)\left\{\begin{array}{c}\mathrm{M} \text { 比 } \\ \%\end{array}\right.$
1. $\mathrm{F}_{2} \mathrm{KMg}_{2.5} \mathrm{Fe}_{0.5}\left(\mathrm{AlSi}_{3} \mathrm{O}_{10}\right)\left\{\begin{array}{c}\mathrm{M} \text { 比 } \\ \%\end{array}\right.$
2. $\mathrm{F}_{2} \mathrm{KMg} 2 \mathrm{Fe}\left(\mathrm{AlSi}_{3} \mathrm{O}_{10}\right) \quad\left\{\begin{array}{c}\mathrm{M} \text { 比 } \\ \%\end{array}\right.$

第 1 表

\begin{tabular}{cccc}
$\mathrm{K}_{2} \mathrm{SiF}_{6}$ & $\mathrm{MgO}$ & $\mathrm{FeO}$ & $\mathrm{Fe}_{2} \mathrm{O}_{3}$ \\
\hdashline 0.5 & 3.0 & - & $(1.5$ \\
23.89 & 26.23 & - & 17.32 \\
0.5 & 2.0 & - & $0 ! 3$ \\
25.04 & 18.34 & - & 10.89 \\
0.5 & 2.5 & 0.5 & - \\
24.58 & 22.50 & 8.02 & - \\
0.5 & 2.0 & 1.0 & - \\
23.75 & 17.39 & 15.49 & -
\end{tabular}

試料溥片を検鏡するに雲母結晶閒にガラス質の外に黒い粒状物及 び針晶を認めた。溥片の顕徽鏡写真は第 1 四の様である。

第 1 四 鉄 $\left(\mathrm{Fe}{ }^{\mathrm{III}}\right)$ 雲母の顕徽鏡写真 $(\times 100)$

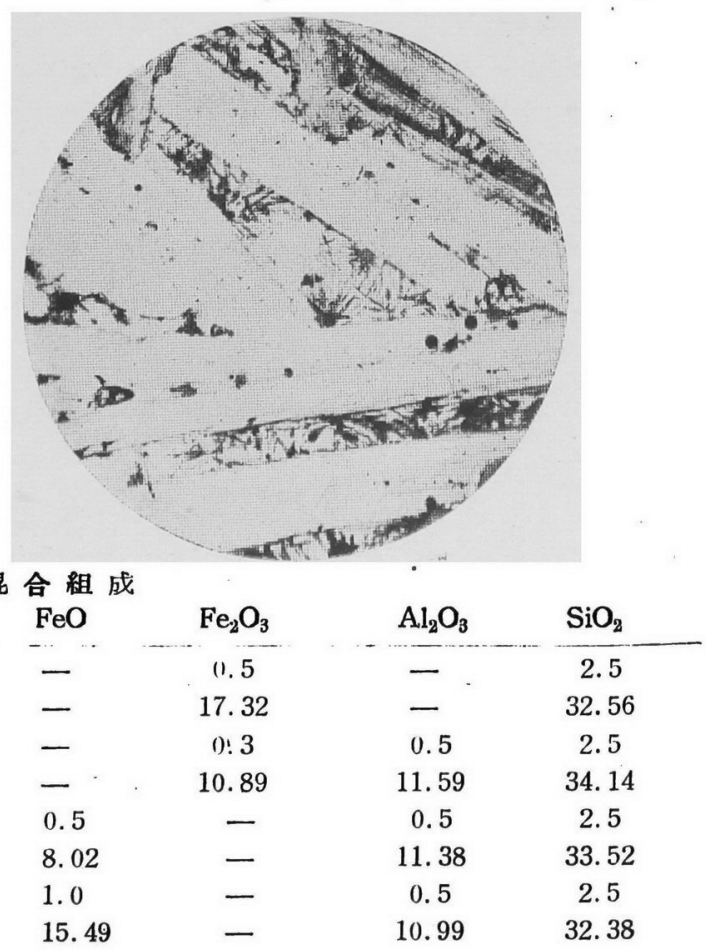

1）大閏信利, 工化 55, 322 (1952).

2）野田稲吉, 大門信利, 工化 49, 125 127 (1946). 


\begin{tabular}{|c|c|c|c|c|c|c|c|}
\hline \multirow{2}{*}{ 3. $\mathrm{F}_{2} \mathrm{KMg}_{1.5} \mathrm{Fe}_{1.5}\left(\mathrm{AlSi}_{3} \mathrm{O}_{10}\right)$} & M比 & 0.5 & 1.5 & 1.5 & - & 0.5 & 2.5 \\
\hline & $\%$ & $22.97^{\circ}$ & 12.61 & 22.47 & - & 10.63 & 31.32 \\
\hline \multirow{2}{*}{ 4. $\mathrm{F}_{2} \mathrm{KMgFe}_{2}\left(\mathrm{AlSi}_{3} \mathrm{O}_{10}\right)$} & M比 & 0.5 & 1.0 & 2.0 & - & 0.5 & 2.5 \\
\hline & $\%$ & 22.24 & 8.14 & 29.01 & - & 10.29 & 3). 32 \\
\hline
\end{tabular}

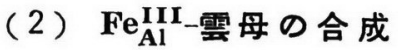

金雲母中の $\mathrm{Mg}$ の一部を $\mathrm{Fe}^{3+}, \mathrm{Fe}^{2+}$ で置きかえようとした。 マグネシウムの大部分を $\mathrm{Fe}$ III で置きかえると, その熔融体の粘 性が大となり，雲母結晶が出来にくくなる。第 1 表 B の組成のも のが割合によい結晶を得た。本組成のるの $400 \mathrm{~g}$ を内容 $400 \mathrm{cc}$ の 磁製の坩堝中にとり, クリプトル電気师で $1380^{\circ} \mathrm{C}$ で完全に熔融 し, 電流を切り放冷した。固化したものは全体が雲母結晶で最大 の単結晶は $5 \mathrm{~mm}^{2}$ であつた。試料薄片を検鏡したところ雲母結 晶間にガラス質の外に金属鉄と思われる粒状及び細長い黒いるの が詰められた。薄片の顕微鏡写真は第 2 図の様であつた。

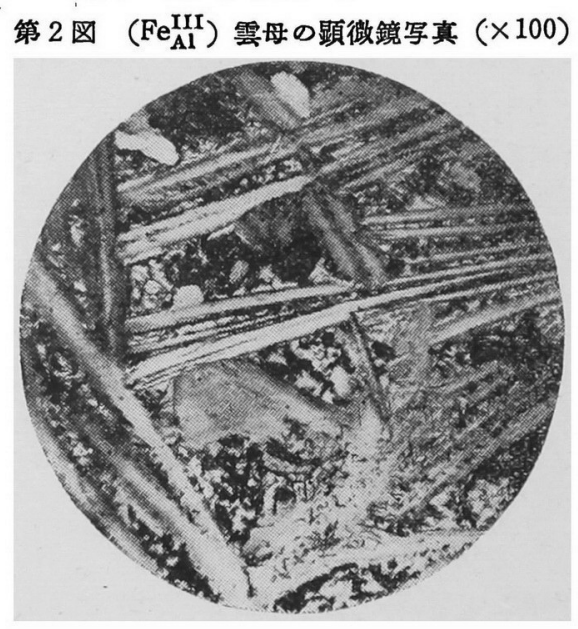

(3) FelI-雲母の合成

$\mathrm{F}_{2} \mathrm{~K}\left(\mathrm{MgFe}^{\mathrm{II}}\right)_{3}\left(\mathrm{AlSi}_{3} \mathrm{O}_{10}\right)$ に相当する雲母を合成しょうとし た。目的とした雲母及び原料組成を第 1 表 $1 ， 2 ， 3 ， 4$ 亿示寸。 $\mathrm{FeO}$ の量が増加するに従つて混合物の融点は低下する。1，2，3 の組成のものは熔融物全体が雲母結晶化しているが，4の雲母の 生成量は少量であつた。又 $\mathrm{Mg}$ の全部を Fe で置きかえたるのか らは雲母が得られなかつた。3の組成のるのを内容 $400 \mathrm{cc}$ の磁製 の坩佩中に約 $400 \mathrm{~g}$ を入れ又雲囲気を完全に還元性にするために 油煙を加えクリプトル電気炉で $1350^{\circ} \mathrm{C}$ で完全に熔融し電流をき り放冷して雲母を得た。得たものは青味を有する黒色の雲母であ 第 3 図 $\left(\mathrm{Fe}^{\mathrm{II}}\right)$ 雲母の顕徽鏡写真 $(\times 100)$

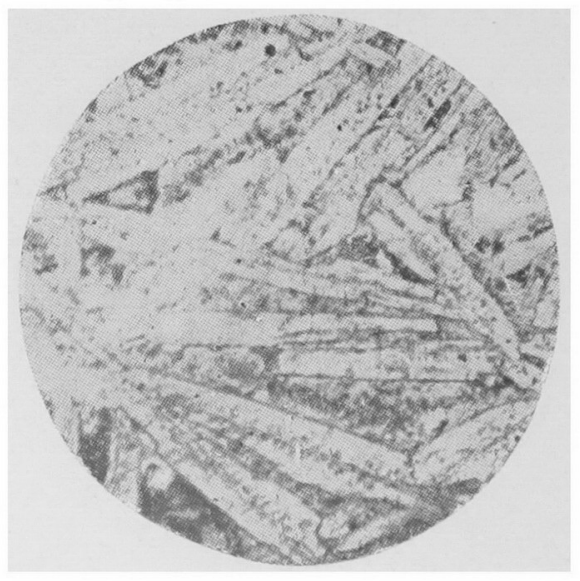

つた。最大の単結晶は $2 \mathrm{~mm}^{3}$ であつた。又坩佩の下部には金属 鉄の塊があつた。試料薄片を検鏡したところ雲母結晶間に一办の 長さ 1/300 mm の立方体結晶らしきもの改び $1 / 300 \mathrm{~mm}$ 位の黒 色䊀状物の外にガラス質があつた。薄片の影钽鏡写真は第 3 図の 様であつた。

\section{（4）鉄雲母の光学的性質及び比重の測定}

マンガン雲母1) の場合と同様にして光学的性貿及び比重を湘定 した。その結果を第 2 表に示す。

第 2 表 鉄雲母の光学的性質及び比重 届折率襣㐿折光軸角多色性 比重 $\overbrace{\beta}^{\gamma} \cdot(\gamma-\alpha) \quad 2 \mathrm{E}, 2 \mathrm{~V} \quad \mathrm{X}<\mathrm{Y}=\mathrm{Z} \quad d_{4}^{15}$

\begin{tabular}{|c|c|c|c|c|c|c|c|c|}
\hline $\mathrm{Fe}^{\mathrm{III}}$-雲母 & 1.567 & 1.568 & 0.033 & 18 & 11 & 黄 & 褐 & 2.975 \\
\hline $\mathrm{Fe}_{\mathbf{A l}}^{\mathrm{III}}$-雲母 & 1.543 & 1.543 & 0.027 & 18 & 11 & & & \\
\hline 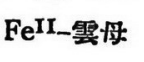 & 1.539 & 1.540 & 0.025 & 18 & 11 & & 带䋨 & \\
\hline
\end{tabular}

第 3 表 吸光保数湘定用試料の採取量

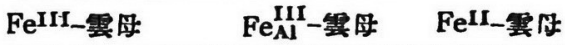

\begin{tabular}{|c|c|c|c|}
\hline 試料の採取量 & $\left(\mathrm{mg} / 3.36 \mathrm{~cm}^{2}\right) 6.40$ & 48.9 & 74.6 \\
\hline 試料の厚さ & $\left(\times 10^{-3} \mathrm{~cm}\right) \quad 6.4$ & 5.0 & 7.6 \\
\hline
\end{tabular}

(5) 吸光 保 数

マンガン雲母1) の場合と同様にして湘定した。用いた試料板上 の試料の採取量は第 3 表の通りである。透過率の湘定值より $\mathbf{F e}^{\mathbf{I I I}}$ 雲母, $\mathrm{Fe}_{\mathrm{Al}}^{\mathrm{III}}$ 雲母及び $\mathrm{Fe}$ II 雲母を夫々 $0.5 \mathrm{~mm}, 0.1 \mathrm{~mm}, 0.5$ $\mathrm{mm}$ の厚さに換算した吸光係数を求め夫々第 4 図に示した。

\section{第 4 図鉄雲母の吸光保数}

$\mathrm{Fe}^{\mathrm{III}}$ : $\mathrm{Fe}^{\mathrm{III}}$-雲母の吸光保数 (厚さ $0.5 \mathrm{~mm}$ )

$\mathrm{Fe}^{\mathrm{II}}$ : $\mathrm{Fe}^{\mathrm{II}}$-雲母の吸光保数（厚さ $0.5 \mathrm{~mm}$ )

$\mathrm{Fe}_{\mathrm{AI}}^{\mathrm{III}}: \mathrm{Fe}_{\mathrm{Al}}^{\mathrm{III}}$-雲母の吸光保数（厚さ $0.1 \mathrm{~mm}$ )

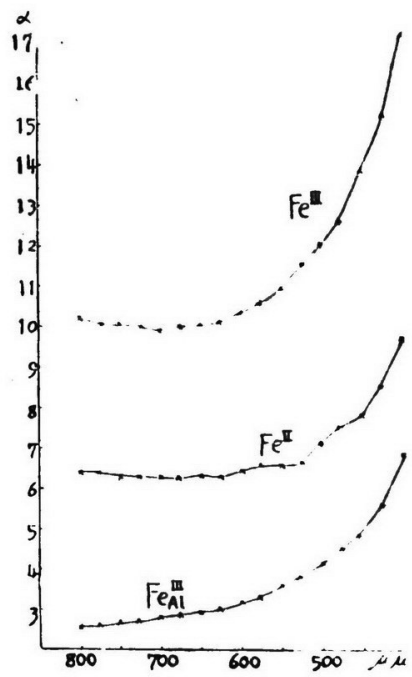

\section{（6）生成雲母の化学組成}

マンガン雲母1) の場合と同様にして訊料をつくり，カリウム， 珪酸及び弗素はマンガン雲母”の場合と同様にして分襍定量し た。 $\mathrm{Al}, \mathrm{Mg}, \mathrm{Fe}$ は試料を硫酸と弗酸により処理し、 $\mathrm{NH}_{4} \mathrm{Cl}$ ， 
$\mathrm{NH}_{4} \mathrm{OH} に て \mathrm{Al}$ と $\mathrm{Fe}$ を $\mathrm{Mg}$ より分離した。定量法はマンガ ン雲母の場合と同様にして行つた。但し $\mathrm{Fe}^{\mathrm{II}}$ は殉料を硫酸と弗 酸にて処理し，弗酸の全部が揮散しない内に $\mathrm{KMnO}_{4}$ で滴定し た。かくして得た結果を第 4 表に示す。

\begin{tabular}{|c|c|c|c|c|c|c|c|}
\hline & $\begin{array}{c}\text { 第 } 4 \\
\mathrm{~K}_{2} \mathrm{O}\end{array}$ & $\begin{array}{r}\text { 鉄 } \\
\mathrm{MgO}\end{array}$ & $\begin{array}{l}\mathrm{FeO} \\
\mathrm{FeO}\end{array}$ & $\begin{array}{l}\text { の 分 析 } \\
\mathrm{Fe}_{2} \mathrm{O}_{3}\end{array}$ & $\begin{array}{l}\mathrm{T} \\
\mathrm{Al}_{2} \text { 值 } \\
\mathrm{O}_{3}\end{array}$ & $\mathrm{SiO}_{2}$ & F \\
\hline $\mathrm{Fe}^{\mathrm{III}}$-雲母 & 10.12 & 25.11 & 2.77 & 10.88 & 3.68 & 42.02 & 7.71 \\
\hline $\mathrm{Fe}_{\mathrm{Al}}^{\mathrm{III}}$-雲度 & 10.11 & 26.77 & 2.35 & 4. 41 & 13.62 & 41. 16 & 7.99 \\
\hline $\mathrm{Fe}^{\mathrm{II}}$-雲母 & 10.62 & 24. 15 & 6.80 & - & 11.08 & 42.98 & 7.08 \\
\hline
\end{tabular}

第 4 表の分析値より化学式を次の様に定めた。

$\mathrm{Fe}^{\mathrm{III}}$-雲好 $\left(\mathrm{F}_{1.80} \mathrm{O}_{0.20}\right) \mathrm{K}_{0.9 j} \mathrm{Mg}_{2.76} \mathrm{Fe} \mathrm{lI}_{0.17} \mathrm{Fe}^{\mathrm{III}}{ }_{0.03}$ ( $\mathrm{Fe}^{\mathrm{III}}{ }_{0.57}$ $\left.\mathrm{Al}_{0.32} \mathrm{Si}_{3.11} \mathrm{O}_{10.00}\right)$

$\mathrm{Fe}_{\mathrm{A1}}^{\mathrm{III}}$-雲母 $\left(\mathrm{F}_{1.77} \mathrm{O}_{0.23}\right) \mathrm{K}_{0.90} \mathrm{Mg}_{2.80} \mathrm{Fe}^{\mathrm{II}}{ }_{0.14} \mathrm{Fe}^{\mathrm{III}_{0.23}}$ ( $\mathrm{Al}_{1.08}$ $\left.\mathrm{Si}_{2.53} \mathrm{O}_{10.00}\right)$

$\mathrm{Fe}^{\mathrm{II}}$-雲母 $\left(\mathrm{F}_{1.63} \mathrm{O}_{0.37}\right) \mathrm{K}_{0.99} \mathrm{Mg}_{2.62} \mathrm{Fe}^{\mathrm{II}_{0.41}} \mathrm{Al}_{0.05}\left(\mathrm{Al}_{0.83} \mathrm{Si}_{3.13}\right.$ $\mathrm{O}_{10.00)}$

これより $\mathrm{Fe}^{\mathrm{II}}$ は正八面体配位をとり， $\mathrm{Fe}^{\mathrm{III}}$ は正四面体改び
正八面体配位をとることを知つた。

結言

次の化学式に相当する鉄雲母を合成した。

$\mathrm{Fe}^{\mathrm{III}}$-雲母 $\left(\mathrm{F}_{1.80} \mathrm{O}_{0.20}\right) \mathrm{K}_{0.95} \mathrm{Mg}_{2.50} \mathrm{Fe}^{\mathrm{II}_{0.17}} \mathrm{Fe}^{\mathrm{III}} \mathrm{O}_{0.03}\left(\mathrm{Fe}^{\mathrm{III}} \mathrm{l}_{0.67}\right.$ $\left.\mathrm{Al}_{0.32} \mathrm{Si}_{3.11} \mathrm{O}_{10.00}\right)$

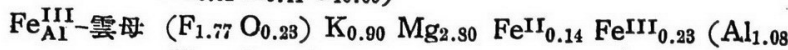
$\mathrm{Si}_{2.88} \mathrm{O}_{10.00}$

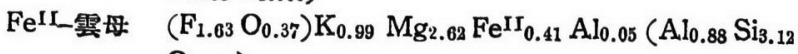
$\mathrm{O}_{10.00}$ )

各雲母の光学的性質, 比重, 及び吸光係数を湘定した。又薄片 の顕徽鏡観察を行つた。

（昭和 26 年 4 月，日本化学会第 4 年会講演）

本研究に関し終始御指導を賜つた野田教授及び化学分析につい て御援助を得た平尾穂氏に深謝の意を表する。何研究費の一部は 文部省科学研究費によったととを附記して感謝の意を表する。

（名古屋大学工学部応用化学教室）（昭和 26 年 11 月 22 日受理）

（159）リチウム雲母の合成及び鉱化剂について

大門信 利

金雲母の理想式 $\mathrm{F}_{2} \mathrm{KMg}_{3}\left(\mathrm{AlSi}_{3} \mathrm{O}_{10}\right)$ 中の正八面体配位をとつ ている 3 個のマダネシウムの内 1 個をリチウムに置きか支，この ために荷電 +1 が減少するのでこれを補5ためにカリウムの代り にパリウム，ストロンチウム文はカルシウムで置きか文，正四面 体配位をとつているアルミニウムを硼素に置きかえ $\mathrm{F}_{2} \mathrm{BaMg}_{2} \mathrm{Li}$ $\left(\mathrm{BSi}_{3} \mathrm{O}_{10}\right), \mathrm{F}_{2} \mathrm{SrMg} 2 \mathrm{Li}\left(\mathrm{BSi}_{3} \mathrm{O}_{10}\right)$ 及び $\mathrm{F}_{2} \mathrm{CaMg}_{2} \mathrm{Li}\left(\mathrm{BSi}_{3} \mathrm{O}_{10}\right)$ を合 成しようとした。尚バリウム，ストロンチウム及びカルシウムは カリウムと㯰換出来, 硼素がアルミニウムと置換出来ることは*
*前報1)2)に発表した。又蚮化郕の探索を行つた。

\section{（I）リチウム雲母の合成}

原料には精製して得た弗化バリウム，弗化ストロンチウム，弗 化カルシウム，炭酸リチウム，無水磞酸及び、ンガン雲母の合 成尚の際に用いたマグネシア，無水珪酸を用いた。合成実験は白 金電気炉により内容 $200 \mathrm{cc}$ の磁製坩堝を用いた。

第 1 表 リチウム零母の原料混合組成

\begin{tabular}{|c|c|c|c|c|c|c|c|c|c|}
\hline & 目的とする雲 & & $\mathrm{MgO}$ & $\mathrm{Li}_{2} \mathrm{CO}_{3}$ & $\mathrm{~B}_{2} \mathrm{O}_{3}$ & $\mathrm{SiO}_{2}$ & $\mathrm{BaF}_{2}$ & $\mathrm{SrF}_{2}$ & $\mathrm{CaF}_{2}$ \\
\hline \multirow{2}{*}{1.} & \multirow{2}{*}{$\mathrm{F}_{2} \mathrm{BaMg}_{2} \mathrm{Li}\left(\mathrm{BSi}_{3} \mathrm{O}_{10}\right)$} & $\{\mathrm{M}$ 比 & 2.0 & 0.5 & 0.5 & 3.0 & 1.0 & - & - \\
\hline & & 1 \% & 15.87 & 7.27 & 6.85 & 35.47 & 34.52 & - & - \\
\hline \multirow{2}{*}{2.} & \multirow{2}{*}{$\mathrm{F}_{2} \mathrm{SrM} \mathrm{M}_{2} \mathrm{Li}\left(\mathrm{BSi}_{3} \mathrm{O}_{10}\right)$} & $\{$ M比 & 2.0 & 0.5 & 0.5 & 3.0 & - & 1.0 & - \\
\hline & & $1 \%$ & 17.95 & 8.23 & 7.75 & 40.11 & - & 25.96 & - \\
\hline 3. & $\mathrm{~F}_{2} \mathrm{CaMg} \mathrm{Li}_{2}\left(\mathrm{BSi}_{3} \mathrm{O}_{10}\right)$ & $\left\{\begin{array}{c}M \text { 比 } \\
\%\end{array}\right.$ & $\begin{array}{c}2.0 \\
20.03\end{array}$ & $\begin{array}{l}0.5 \\
9.18\end{array}$ & 0.5 & 3.0 & - & - & 1.0 \\
\hline
\end{tabular}

（1）BaLi-震母の合成 第 1 表の(1)の混合組成のもの $200 \mathrm{~g}$ を $1150^{\circ} \mathrm{C}$ にて榕螱し， 1 時間 $70^{\circ} \mathrm{C}$ の㓶合にて冷却し最大 $10 \mathrm{~mm}^{2}$ の良く発達した需母結晶を得た。結晶塊の表面には針晶があつ た。試料薄片を検鏡するに雲母結晶間に褐色改び無色のガラス貿 の外に黒色の粒状物（直径 $0.1 / 100 \mathrm{~mm} 2 / 100 \mathrm{~mm}$ ）があつた。 第 1，2 四に薄片の顕设鏡写真を示す。

（2）SrLi-雲母の合成 第 1 表の（2）の混合組成のもの $200 \mathrm{~g}$ を $1160^{\circ} \mathrm{C}$ にて譗融し， 1 時間 $70^{\circ} \mathrm{C}$ の割合にて冷却し最 大 $5 \mathrm{~mm}^{2}$ の雲母結晶を得た。結晶塊の表面には $2 \sim 3 \mathrm{~mm}$ 以下 の鱽晶を認めた。試料薄片を検鏡するに雲母結晶間にガラス質の

1）野田稲吉, 大阴伊利, 豊田等, 工化 47, 499 502(1944).

2）野田稲吉，大門信利，ウタ1，橧協 52，95 98 (1944).

3) 大門信利, 工化 55,322 (1952).
第 1 困 BaLi-雲母の顕微鏡写真 $(\times 100)$

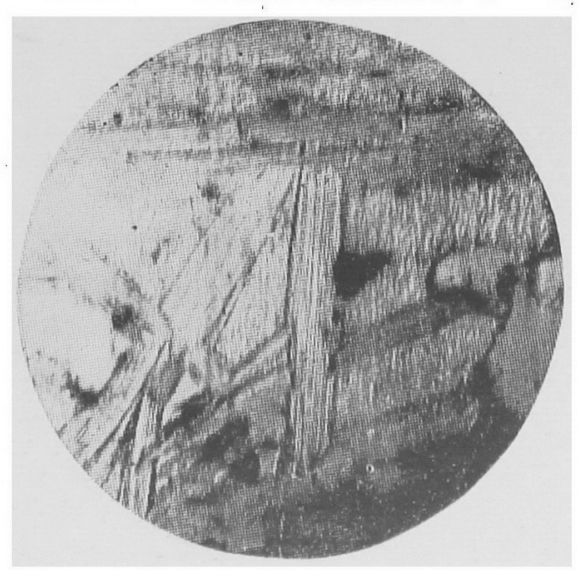

